\title{
Ensefalitis Herpes Simplex pada Anak
}

\author{
Hardiono D Pusponegoro
}

\begin{abstract}
Ensefalitis herpes simplex (EHS) seringkali berakibat fatal. Virus herpes simpleks (VHS) dapat menyerang semua umur tanpa perbedaan jenis kelamin. Angka kejadian EHS adalah 1:(250.000-500.000) populasi/tahun. Pada fase prodromal dapat ditemukan malaise dan disertai demam selama 1-7 hari. Pasien mengalami penurunan kesadaran dan kejang, dapat berupa kejang umum. Gejala neurologi umumnya ditemukan hemiparesis, sedangkan pemeriksaan darah tepi rutin pada EHS tidak efektif. EEG sangat membantu bila ditemukan perlambatan fokal di daerah temporal atau fronto temporal. Titer antibodi terhadap VHS dapat diperiksa dari serum dan cairan serebrospinalis. Pengobatan VHS berupa terapi simtomatis dan suportif ditambah antivirus spesifik (acyclovir). Prognosis pasien EHS yang tidak diobati sangat buruk, sedangkan pada pengobatan dini dengan acyclovir akan menurunkan mortalitas menjadi $28 \%$.
\end{abstract}

Kata kunci: EHS (ensefalitis herpes simpleks) - acyclovir

8 nsefalitis herpes simplex adalah penyebab ensefalitis pada manusia yang seringkali berakibat fatal. ${ }^{1,2}$ Penelitian mengenai efektivitas vidarabin tahun 1977 menunjukkan hasil yang menggembirakan dengan berkurangnya mortalitas dari 70 sampai 40 persen. ${ }^{3}$ Selanjutnya, dua penelitian terkontrol oleh Skoldenberg dan Forsgren ${ }^{4}$ tahun 1985 dan Whitley dkk ${ }^{5}$ tahun 1986 memperlihatkan bahwa acyclovir intravena lebih baik dibandingkan vidarabin dalam pengobatan EHS. Untuk memperoleh hasil yang memuaskan, acyclovir harus diberikan sedini mungkin. ${ }^{5} \mathrm{Di}$ sinilah letak masalahnya, karena diagnosis EHS sering terlambat karena manifestasi klinis yang tidak khas dan kesulitan dalam pembuktian secara laboratorium, karena adanya infeksi memang secara alamiah sulit dibuktikan, fasilitas laboratorium yang terbatas, harga pemeriksaan yang mahal serta kesulitan menginterpretasi hasil pemeriksaan. ${ }^{1}$

\footnotetext{
Alamat korespondensi:

Dr. Hardiono D Pusponegoro Sp.A(K)

Subbagian Saraf Anak, Bagian Ilmu Kesehatan Anak, Fakultas Kedokteran Universitas Indonesia - RS Dr. Cipto Mangunkusumo

Jl. Salemba No. 6, Jakarta 10430, Indonesia.

Telpon (021) 3149161, Fax.: (021) 3913982.
}

Dalam makalah ini akan dibicarakan pentingnya kecurigaan klinis, pengobatan dan cara mengkonfirmasi diagnosis dengan ilustrasi kasus yang ditemukan di Bagian Ilmu Kesehatan Anak FKUI-RSCM.

\section{Kasus}

Pada tahun 1991 sampai dengan 1994, telah ditemukan 11 pasien di Bagian IKA RS Cipto Mangunkusumo, terdiri dari 7 perempuan dan 4 lakilaki. Umur pasien antara 2,5 bulan sampai 11 tahun. Satu kasus berumur 2,5 bulan, 1 kasus 15 bulan, dan 9 kasus lebih dari 3 tahun (Tabel 1).

Tabel 1. Distribusi umur pasien EHS di Bagian IKA RSCM 1991-1994

\begin{tabular}{cc}
\hline Umur (tahun) & Jumlah pasien \\
\hline$<1$ & 1 \\
$1-2$ & 1 \\
$3-5$ & 2 \\
$6-8$ & 2 \\
$9-11$ & 5 \\
\hline
\end{tabular}


Lima pasien mengalami kejang fokal, 5 pasien menderita kejang umum dan 1 kasus tidak kejang. Sebagian besar kejang merupakan kejang berulang dengan waktu singkat. Semua kasus menunjukkan penurunan kesadaran yang bervariasi antara skala 3-6 pada skala koma Glasgow (Tabel 2). Pada pasien nomor 4 hanya memperlihatkan penurunan kesadaran tanpa kejang.
Electroencephalography dilakukan pada semua kasus. Hanya 1 kasus menunjukkan gambaran periodic lateralizing epileptiform discharge, 3 kasus menunjukkan perlambatan satu sisi sedangkan sisanya menunjukkan perlambatan umum. Cairan serebrospinalis normal pada 8 kasus sedangkan 3 kasus menunjukkan pleiositosis ringan dengan sel mononuklear predominan.

Titer antibodi IgG serum terhadap VHS-1 positif

Tabel 2. Hasil pengobatan

\begin{tabular}{|c|c|c|c|c|c|c|}
\hline \multirow[t]{2}{*}{ No } & \multirow[t]{2}{*}{ Umur } & \multirow[t]{2}{*}{$\begin{array}{l}\text { Jenis } \\
\text { Kelamin }\end{array}$} & \multicolumn{2}{|c|}{$\begin{array}{l}\text { Lama manifestasi ensefalitis } \\
\text { (hari) }\end{array}$} & \multirow{2}{*}{$\begin{array}{c}\text { Skala koma } \\
\text { Glassgow } \\
\text { awal }\end{array}$} & \multirow[t]{2}{*}{ Hasil pengobatan } \\
\hline & & & $\begin{array}{l}\text { sebelum } \\
\text { perawatan }\end{array}$ & $\begin{array}{c}\text { sebelum } \\
\text { pengobatan }\end{array}$ & & \\
\hline 1 & $2,5 \mathrm{bln}$ & $\mathrm{P}$ & 3 & 4 & 6 & Hidup tanpa gejala sisa \\
\hline 2 & 10 thn & $\mathrm{L}$ & 1 & 1 & 6 & Hidup tanpa gejala sisa \\
\hline 3 & 7 thn & $\mathrm{P}$ & 2 & 2 & 5 & Hidup tanpa gejala sisa \\
\hline 4 & 10 thn & $\mathrm{L}$ & 2 & 2 & 6 & Hidup tanpa gejala sisa \\
\hline 5 & 4,5 thn & $\mathrm{P}$ & 1 & 1 & 5 & Hidup tanpa gejala sisa \\
\hline 6 & 10 thn & $\mathrm{P}$ & 3 & 3 & 3 & Hidup tanpa gejala sisa \\
\hline 7 & 4,5 thn & $\mathrm{P}$ & 1 & 1 & 5 & Hidup tanpa gejala sisa \\
\hline 8 & $15 \mathrm{bln}$ & $\mathrm{P}$ & 2 & 2 & 4 & Hidup, gejala sisa berat \\
\hline 9 & 6 thn & $\mathrm{L}$ & 14 & 15 & 4 & Meninggal hari 5 \\
\hline 10 & 11 thn & $\mathrm{L}$ & 1 & 4 & 6 & Meninggal hari 19 \\
\hline 11 & 9 thn & $\mathrm{P}$ & 1 & 3 & 5 & $\begin{array}{l}\text { Meninggal hari } 11 \text { karena } \\
\text { bronkopneumoni }\end{array}$ \\
\hline
\end{tabular}

Salah satu indikator keberhasilan terapi adalah pulihnya kesadaran dengan cepat, hanya dalam waktu 1-3 hari, kemudian pasien akan hidup tanpa gejala sisa. Delapan kasus menunjukkan hemiparesis. Rangsang meningeal menyerupai meningitis ditemukan pada 2 kasus, keduanya menunjukkan hasil biakan yang negatif. Semua manifestasi klinis tersebut tidak khas dan sulit dibedakan dengan ensefalitis karena virus lain, kecuali kejang fokal dan hemiparesis.

Computerized Tomography Scanning dilakukan pada 5 kasus, disebabkan kesulitan membawa pasien ke ruang CT scan karena mereka menggunakan respirator dan faktor biaya. CT scan pasien 8 dilakukan pada hari ke8 dan menunjukkan hipodensitas di daerah temporal. Tiga kasus menunjukkan atrofi serebri sedangkan 1 kasus menunjukkan CT scan yang normal. pada semua pasien sedangkan IgM hanya positif pada 1 pasien. IgG terhadap HSV-2 positif pada 10 kasus sedangkan IgM negatif pada semua kasus. Pemeriksaan antibodi dalam cairan serebrospinalis dilakukan pada 4 pasien, semua menunjukkan hasil negatif. Karena biaya pemeriksaan yang tinggi, jarang sekali dilakukan ulangan pemeriksaan kadar antibodi.

Semua pasien mendapat acyclovir $30 \mathrm{mg} / \mathrm{kgbb} /$ hari, dibagi dalam 3 dosis. Acyclovir dilarutkan dalam $100 \mathrm{ml}$ larutan garam fisiologis dan diberikan dalam 1 jam melalui infus selama 10 hari. Enam kasus sembuh tanpa gejala sisa. Satu kasus menunjukkan hemiparesis ringan terutama pada lengan. Pasien 8 mengalami status konvulsivus selama 2 hari di rumah sakit lain sebelum dirujuk ke rumah sakit Cipto Mangunkusumo. Pasien memperlihatkan gejala sisa 
berat berupa tetraparesis spastik, retardasi mental berat dan mikrosefali.

Tiga kasus meninggal, 2 orang disebabkan oleh ensefalitis sedangkan 1 orang lainnya menunjukkan perbaikan kesadaran tetapi kemudian meninggal disebabkan bronkopneumoni. Pasien nomor 9 meninggal pada hari ke-5. Pasien nomor 10 mengalami 2 bangkitan kejang fokal yang menjadi umum masingmasing selama 20 menit, pasien meninggal pada hari ke-19. Pasien nomor 11 mengalami kejang selama 4 jam. Setelah pengobatan, pasien memperlihatkan perbaikan kesadaran tetapi kemudian meninggal karena bronkopneumonia dan gagal napas.

Kasus yang meninggal mendapat acyclovir 3, 4 dan 15 hari setelah onset ensefalitis. Kasus nomor 8 yang mengalami status konvulsivus yang tidak dapat diatasi di rumah sakit lain mendapat acyclovir 3 hari setelah awitan ensefalitis. Kasus yang tidak mengalami gejala sisa mendapat acyclovir 3 hari setelah awitan (2 kasus) dan 1-2 hari setelah awitan pada 5 kasus.

Dari laporan kasus di atas, terlihat bahwa pemberian acyclovir secara dini sangat diperlukan pada EHS. Fasilitas laboratorium kami masih sangat terbatas dan biaya pemeriksaan sangat tinggi, menyebabkan sulitnya konfirmasi diagnosis. Pegangan yang dianut saat ini adalah pemberian acyclovir pada pasien yang menunjukkan demam, kejang terutama kejang fokal, penurunan kesadaran dan hemiparesis, serta melakukan pemeriksaan laboratorium. ${ }^{16}$

\section{Patogenesis dan Patologi}

Virus herpes simplex dapat menyerang semua umur, tanpa predileksi jenis kelamin. ${ }^{1}$ Infeksi primer maupun infeksi sekunder dapat menyebabkan EHS. ${ }^{5}$ Angka kejadian adalah 1 dalam 250. 000-500.000 populasi per tahun. ${ }^{2}$ Virus ini mempunyai predileksi pada lobus frontalis dan lobus temporalis otak. Bagaimana mekanisme virus dapat mencapai otak dan mengapa ada predileksi tertentu masih menjadi tanda tanya. Diduga VHS dapat mencapai otak melalui traktus olfaktorius atau ganglion trigeminal (hidup dalam keadaan laten), melalui cabang tentorial dari nervus trigeminus, melalui duramater lalu mencapai korteks frontalis atau temporalis. ${ }^{6}$

Lesi korteks biasanya asimetris. ${ }^{6}$ Otopsi menunjukkan nekrosis korteks lobus temporalis dengan perdarahan petekial, edema otak, serta pelebaran pembuluh darah korteks. Terlihat pula hiperemia serta infiltrasi perivaskular oleh sel mononuklear, makrofag dan sel plasma pada meningen dan korteks serebri. ${ }^{1,6}$ Pada EHS dapat ditemukan herniasi unkus dan serebelum sebagai komplikasi peninggian tekanan intrakranial.

\section{Manifestasi Klinis}

Ensefalitis herpes simplex dapat bermanifestasi akut atau subakut. Pada fase prodromal, pasien mengalami malaise dan demam yang berlangsung 1-7 hari. ${ }^{1,7}$ Manifestasi ensefalitis dimulai dengan sakit kepala, muntah, perubahan personalitas dan gangguan daya ingat yang sangat sulit dideteksi terutama pada anak kecil. ${ }^{1}$ Kemudian pasien dapat mengalami kejang dan penurunan kesadaran. Kejang dapat berupa kejang fokal atau umum.

Perlu diingat bahwa kejang umum pada EHS dapat diawali oleh kejang fokal yang berkembang menjadi kejang umum. Bila kejang fokal sangat singkat, orangtua seringkali tidak mengetahui. Empat puluh persen pasien datang di rumah sakit dalam keadaan koma sedangkan sisanya dalam keadaan letargi. ${ }^{1,2}$ Koma adalah faktor prognosis yang sangat buruk, pasien yang mengalami koma seringkali meninggal atau sembuh dengan gejala sisa yang berat. Kematian biasanya terjadi dalam 2 minggu pertama.

Pemeriksaan neurologis seringkali menunjukkan adanya hemiparesis. Menurut pengalaman penulis, hemiparesis adalah manifestasi fokal terpenting. Beberapa kasus dapat menunjukkan disfasia, ataksia, gangguan sistem otonom, paresis saraf kranialis, dan edema papil N II. Kadang-kadang manifestasi klinis menyerupai meningitis aseptik tanpa manifestasi ensefalitis yang jelas. ${ }^{1}$ Jelaslah bahwa manifestasi klinis sangat tidak spesifik terutama pada anak dan diagnosis EHS sangat memerlukan kecurigaan klinis yang kuat. Secara praktis, kita harus selalu memikirkan kemungkinan EHS bila menjumpai seorang anak dengan demam, kejang terutama kejang fokal dan gejala neurologis fokal lain seperti hemiparesis atau disfasia dengan penurunan kesadaran yang progresif. ${ }^{8,9}$

\section{Pemeriksaan Laboratorium}

Pemeriksaan darah tepi rutin pada EHS tidak spesifik. 
Jumlah leukosit darah tepi dapat normal atau sedikit meningkat, kadang-kadang dengan pergeseran ke kiri. ${ }^{1,7}$ Sembilan puluh persen pasien memperlihatkan cairan serebrospinalis abnormal. Pada fase awal, leukosit polimorfonuklear predominan, kemudian berubah menjadi limfositosis. Jumlah sel bervariasi antara 10 sampai 1000 sel per mm3. Kadang-kadang ditemukan sel darah merah dengan cairan likuor serebrospinalis yang santokrom. ${ }^{1,7}$ Kadar protein cairan serebrospinalis dapat meningkat sampai $50-200 \mathrm{mg} / \mathrm{dl}$ sedangkan kadar glukosa dapat menurun. ${ }^{7}$

\section{Elektroensefalografi}

Electroencephalography sangat membantu diagnosis bila ditemukan gambaran periodic lateralising epileptiform discharge atau perlambatan fokal di daerah temporal atau frontotemporal. ${ }^{10}$ Lebih sering EEG hanya memperlihatkan perlambatan umum yang tidak spesifik dan menunjukkan disfungsi otak menyeluruh.

\section{Neuroradiologi}

Gambaran yang agak khas pada CT scan terlihat pada $50-75 \%$ kasus, yaitu gambaran daerah hipodens di lobus temporalis atau frontalis, kadang-kadang meluas sampai lobus oksipitalis. ${ }^{11,12}$ Daerah hipodens ini disebabkan nekrosis jaringan otak dan edema otak. ${ }^{13}$ Setelah pemberian kontras, dapat dilihat daerah yang lebih menyangat mengikuti kontur sulkus dan girus, atau membatasi daerah hipodens, atau membentuk suatu cincin. ${ }^{13}$ Gambaran khas $C T$ scan baru terlihat setelah minggu pertama. Magnetic resonance imaging (MRI) lebih sensitif dan memperlihatkan hasil lebih awal dibandingkan CT scan. ${ }^{14}$ Penggunaan single photon emission computed tomography (SPECT) dengan Tc-99m-HMPAO dapat memperlihatkan daerah hipoperfusi di lobus temporalis atau frontalis pada fase awal. ${ }^{15}$

\section{Pemeriksaan Serologis}

Isolasi virus tidak dilakukan secara rutin karena sangat jarang menunjukkan hasil yang positif. ${ }^{7}$ Titer antibodi terhadap VHS dapat diperiksa dalam serum dan cairan serebrospinalis. Titer antibodi dalam serum tergantung apakah infeksi merupakan infeksi baru atau infeksi rekurens. Pada infeksi baru, antibodi dalam serum menjadi positif setelah 1 sampai beberapa minggu, sedangkan pada infeksi rekurens kita dapat menemukan peninggian titer antibodi dalam 2 pemeriksaan, fase akut dan rekonvalesen. ${ }^{7}$ Kenaikan titer 4 kali lipat pada fase rekonvalesen merupakan tanda bahwa infeksi VHS sedang aktif. ${ }^{1,15}$ Perlu diingat bahwa peningkatan kadar antibodi serum belum membuktikan bahwa ensefalitis disebabkan VHS.

Titer antibodi dalam cairan serebrospinalis merupakan indikator yang lebih baik, karena hanya diproduksi bila terjadi kerusakan sawar darah-otak. Sayang sekali kemunculan antibodi dalam cairan serebrospinalis sering terlambat dan seringkali baru dapat dideteksi 12 hari setelah awitan. ${ }^{1}$ Hal ini merupakan kendala terbesar dalam menegakkan diagnosis EHS, dan hanya berguna sebagai diagnosis retrospektif. Penelitian mengenai cara diagnosis yang lebih baik telah dilakukan, terutama dengan menggunakan polymerase chain reaction (PCR), yang biasanya positif lebih awal dibandingkan titer antibodi. ${ }^{15}$

\section{Biopsi Otak}

Baku emas dalam diagnosis EHS adalah biopsi otak dan isolasi virus dari jaringan otak. ${ }^{5}$ Banyak pusat penelitian tidak ingin mengerjakan prosedur ini karena berbahaya dan kurangnya fasilitas untuk isolasi virus. ${ }^{8}$ Kelemahan lain dari prosedur ini adalah kemungkinan ditemukannya hasil negatif palsu karena biopsi dilakukan bukan pada tempat yang tepat. ${ }^{1}$

\section{Penatalaksanaan}

Pengobatan simtomatik dan suportif sama dengan penatalaksanaan ensefalitis lain, termasuk pengobatan kejang, edema otak, peninggian tekanan intrakranial, hiperpireksia, gangguan respirasi dan infeksi sekunder. Perbedaan utama adalah pada EHS kita dapat memberikan antivirus yang spesifik.

Pengobatan dengan antivirus harus dimulai sedini mungkin untuk mencegah terjadinya nekrosis hemoragis yang ireversibel yang biasanya terjadi 4 hari 
Sari Pediatri, Vol. 2, No. 2, Agustus 2000

setelah awitan ensefalitis. ${ }^{1} \mathrm{Hal}$ ini menimbulkan kesulitan, karena pada fase awal tidak terdapat cara untuk membuktikan diagnosis. Patokan yang dianut saat ini adalah pengobatan segera pada pasien yang dicurigai mengalami EHS, kemudian pengobatan dapat dilanjutkan atau dihentikan sesuai konfirmasi laboratorium.

Vidarabin telah diteliti pada tahun 70-an dan dapat menurunkan mortalitas dari $70 \%$ sampai 40\%. Saat ini, acyclovir intravena telah terbukti lebih baik dibandingkan vidarabin dan merupakan obat pilihan pertama. ${ }^{4,5}$ Preparat acyclovir tersedia dalam kemasan 250mg dan 500mg, yang harus diencerkan dengan air atau larutan garam fisiologis. Dosis adalah $30 \mathrm{mg} / \mathrm{kgbb} / 24 \mathrm{jam}$ dibagi dalam 3 dosis. Cara pemberian secara perlahan-lahan dengan pompa suntik atau diencerkan lagi menjadi $100 \mathrm{ml}$ dalam larutan glukosa 5\% diberikan selama 1 jam. Efek samping adalah peningkatan kadar ureum dan kreatinin, tergantung kadar obat dalam plasma. Pemberian acyclovir perlahan-lahan akan mengurangi efek samping ini.

\section{Prognosis}

Prognosis EHS sangat buruk pada pasien yang tidak diobati. Kematian karena EHS mencapai 70-80\% setelah 30 hari dan meningkat menjadi $90 \%$ dalam 6 bulan. ${ }^{3}$ Pengobatan dini dengan acyclovir akan menurunkan mortalitas menjadi 28\%.5 Gejala sisa lebih sering ditemukan dan lebih berat pada pasien yang tidak diobati.

\section{Ucapan terima kasih}

Terima kasih kepada PT. Burroughs Wellcome Indonesia yang menyediakan acyclovir intravena (Zovirax) bagi penelitian ini.

\section{Daftar Pustaka}

1. Mindel A. Herpes simplex virus. London: SpringerVerlag, 1989.

2. Whitley RJ. Herpes simplex virus infections of the central nervous system. A review. Am J Med 1988; 85 (Supp 2A):61-7.

3. Whitley RJ, Soong SJ, Dolin R et al. Adenine arabinoside therapy of biopsy-proved herpes simplex encephalitis. New Engl J Med 1977; 297:289-94.

4. Skoldenberg B, Forsgren M. Acyclovir versus vidarabine in herpes simplex encephalitis. Scan J Infect Dis 1985; 47 (Supp.):89-96.

5. Whitley RJ, Alford CA, Hirsch MS et al. Vidarabine versus acyclovir therapy in herpes simplex encephalitis. N Engl J Med 1986; 314:144-9.

6. Drachman DA, Adams RD. Herpes simplex and acute inclusion body encephalitis. Arch Neurol 1962; 7:45-63.

7. Oxman MN. Herpes simplex encephalitis and meningitis. Dalam Braude Al, Davis CE, Fierer J penyunting. Infectious diseases and medical microbiology, $2^{\text {nd }}$ ed. Philadelphia: Saunders 1986:h.1114-30.

8. Brett EM. Herpes simplex virus encephalitis in children. Br Med J 1986; 293:1388-9.

9. Braun P. The clinical management of suspected herpes virus encephalitis. A decision-analytic view. Am J Med 1980; 69:895-902.

10. Smith JB, Westmoreland BF, Reagan TJ, Sandok BA. A distinctive clinical EEG profile on herpes simplex encephalitis. Mayo Clin Proc 1975; 50:469-74.

11. Dublin AB, Merten DF. Computed tomography in the evaluation of herpes simplex encephalitis. Radiology 1977; 125:133-4.

12. Greenberg SB, Taber L, Septimus E, Kohl S, Puck J. Computerized tomography in brain biopsy-proven herpes simplex encephalitis. Arch Neurol 1981; 38:58-9.

13. Enzman RE, Ranson B, Norman D, Talbert E. Computed tomography of herpes simplex encephalitis. Radiology 1978; 129:419-25.

14. Scroth G, Gawehn J, Thron A, Vallbracht A, Voight K. Early diagnosis of herpes simplex encephalitis by MRI. Neurology 1987; 17:179-89.

15. Skoldenberg B. Herpes simplex encephalitis. Journ of the Internat. Herpes Manag. Forum 1994; 1:61-6.

16. Pusponegoro HD. The treatment of herpes simplex encephalitis with intravenous acyclovir. Disampaikan pada Paediatrics Neurology congress: Past, Present \& Future, 12 June 1994, Penang, Malaysia. 